\title{
Proses Mineralojisinin Flotasyon Tesis Performans Analizinde Kullanımı
}

\section{Use of Process Mineralogy for Flotation Plant Performance Analysis}

\author{
ILKAY B. CAN ${ }^{\star 1}$, ZAFIR EKMEKÇi ${ }^{1}$, N. METIN CAN ${ }^{1}$ \\ ${ }^{1}$ Hacettepe Üniversitesi, Maden Mühendisliği Bölümü, 06800 Beytepe - Ankara, Türkiye \\ Geliș (received) : 23 Ağustos (August) 2018 \\ Kabul (accepted) : 24 Kasım (November) 2018
}

öz

Zenginleștirme tesislerinin tasarımı ve optimizasyonu çalıșmalarında cevher yatağının mineralojisi çok önemli bir yere sahiptir. Zenginleștirme tesisinin farklı noktalarından alınan cevher örneklerine uygulanan detaylı mineralojik analizler sayesinde, zenginleștirme performansını sııılayan ana etkenler ve performansın artırlabilmesi için yapılması gereken düzenlemeler hakkında yorum yapılabilmektedir.

Bu çalıșmada, altın içeren kompleks bakır-arsenikli sülfürlü cevherin ișlendiği bir flotasyon tesisinin performansı detaylı kantitatif mineraloji verileri kullanılarak değerlendirilmiștir. Flotasyon tesisinin beslemesi, bakır ve pirit konsantreleri ve bakır süpürme artığı akıșlarından numuneler alınarak kimyasal ve mineralojik analizler yapıımıș, QemSCAN ile ayrıca konsantrelerdeki altının davranımı da incelenmiștir. Flotasyon beslemesinin mineralojik analiz sonuçları minerallerin serbestleșme derecesinin $-45 \mu$ m'de ancak \%60 seviyesine ulașıı̆ı̆ıı göstermiș, dolayısıyla daha ince tane boyuna öğütülen bir flotasyon beslemesiyle bakır veriminin artabileceği öngörülmüștür. Bakır konsantresinin ise serbest pirit taneleriyle kirlendiği belirlenmiș, buna göre flotasyon ișletme koșullarının da gözden geçirilmesi gerektiği ortaya çıkmıștır. Devrede bakır kaybı açısından en önemli akıșın süpürme flotasyonu artığı olduğu ve bu kaybın özellikle en ince tane boyunda ve serbest formda olduğu belirlenmiștir. Cevherde bulunan altın tanelerinin ise daha çok nabit formda olduğu, \%80'ininin 20 m'den küçük ve genellikle pirit ve enargitle bağlı bulunduğu gözlenmiștir.

Anahtar Kelimeler: Sülfürlü mineraller, flotasyon, kantitatif mineralojik analiz, altın, serbestleșme.

\begin{abstract}
Mineralogy of the ore deposit has very great importance in the design and optimization of concentration plants. With detailed mineralogical analyzes applied to the ore samples taken from different points of the concentration plant, comments can be done on the main factors limiting the enrichment performance and the necessary arrangements to improve performance.

In this study, the performance of a flotation plant, treating complex copper-arsenic sulfide ore containing gold, was evaluated using detailed quantitative mineralogical data. Chemical and mineralogical analyzes were carried out by taking the samples from the flotation feed, copper and pyrite concentrates and copper scavenger tail streams, and the gold behavior in the concentrates was also examined by QemSCAN. Mineralogical analysis of the feed revealed that the liberation degree of minerals reached only $60 \%$ at $-45 \mu \mathrm{m}$, so it is anticipated that the copper recovery could be increased by finer flotation feed. It was determined that the copper concentrate was diluted with free pyrite particles, and accordingly the flotation operating conditions had to be revised. The most important stream in terms of copper loss in the circuit was determined as the scavenger flotation tail, and that loss was particularly via finest size fraction and liberated form. It has been observed that the gold grains found in the ore are mostly in native form, $80 \%$ of which are smaller than $20 \mu \mathrm{m}$ and are usually associated to pyrite and enargite.
\end{abstract}

Kuvars damarlardaki sıvı kapanımlarının homojenleșme sıcaklıkları $160^{\circ}$ C'den $400^{\circ}$ C'nin üzerinde geniș bir aralıkta dağılım göstermektedir. Sıvı kapanımları genelde karbon dioksitçe zengin olup yüksek tuz içeriklidirler (\% 20-33 NaCl eșdeğeri).

Altınlı kuvars damarları, metal içeriği, yan kayaç alterasyonu, mineraloji, olușum koșulları ve yapısal kontrol açısından orojenik altın yatakları ile benzer özelliklere sahiptir. Damarların migmatitlerle, yüksek dereceli metamorfik kayaçlar ve granitoidlerle olan mekânsal birlikteliği bunların olușumunun Orta Anadolu'daki metamorfizma, yükselme ve/veya migmatitik domlașma ve granitoid yerleșimi ile ilgili olduğunu ifade etmektedir.

Keywords: Sulphide minerals, flotation, quantitative mineralogical analysis, gold, liberation.

*i.B. Can

e-posta: ilkay@hacettepe.edu.tr 


\section{GiRiș}

Enargit $\left(\mathrm{Cu}_{3} \mathrm{AsS}_{4}\right)$ ve tennantit $\left(\mathrm{Cu}_{12} \mathrm{As}_{4} \mathrm{~S}_{13}\right)$ arsenik içeren bakır mineralleri olup genellikle kalkopirit (Cu$\left.\mathrm{FeS}_{2}\right)$, kalkozin $\left(\mathrm{Cu}_{2} \mathrm{~S}\right)$ gibi diğer bakır sülfür mineralleriyle birlikte bulunurlar. Enargit ve tennantitin diğer bakır sülfürlü minerallerden palp potansiyelinin kontrolü gibi koșullarla seçimli olarak ayrılması yönünde çalıșmalar olsa da (Fornasiero vd., 2001; Lotter vd. 2016) genellikle flotasyon davranımlarının benzer olması sebebiyle ayrılmaları zor ve ekonomik olmadığı için birlikte zenginleștirilirler (Plackowski vd., 2012). Enargit ve tennantit ile birlikte bulunan bakır sülfürlü cevherlerde altın içeriğine de sık rastlanılmakta, ancak bazen olușum koșulları nedeniyle bu altın varlığına doğrudan liç yöntemleri uygulanamamaktadır. Bu durumda özellikle altının sülfürlü minerallerle olan birlikteliği mineralojik olarak tespit edildiğinde, zenginleștirme yöntemi olarak toplu flotasyon yöntemi tercih edilebilmektedir (Curreli vd., 2005; Cabri vd. 2005).

Enargit ve tennantit ile birlikte kalkopirit, bornit, digenit, kalkozin gibi diğer bakır minerallerini içeren sülfürlü cevherler mineral çeșitliliği nedeniyle genellikle "kompleks" olarak adlandırılmakta, bu minerallerin olușum tane büyüklüğü ve cevher içindeki dağılımları da özellikle öğütme serbestleșme boyunun belirlenmesi ve daha efektif akım șeması geliștirme açısından oldukça önem tașımaktadır (Petruk, 2000; Tungpalan vd., 2015, Sutherland, 2007). Dolayısıyla mineral miktarını ifade eden modal mineraloji ve cevher yapı-dokusu jeolojik bilgiyi, cevhere uygun seçilen zenginleștirme yöntemi ise prosese ilișkin bilgiyi temsil etmektedir. Bu iki bilgi bir arada kullanıldığında üretim yönteminde elde edilecek ürünün verim ve tenörünü teorik olarak tahmin etmek mümkün olmaktadır (Lund vd., 2015). Mineralojik bilgilerin cevher yatağının tanımlanması, zenginleștirme ișleminin tasarımı ve elde edilen konsantrelerin izabesi așamalarında karșılașılabilecek olası sorunların belirlenmesi ve çözüm önerilerinin geliștirilmesi amacıyla kullanılması genel olarak proses ya da uygulamalı mineraloji olarak adlandırılmaktadır. Cevher hazırlama ișlemlerinin verimliliği ise genellikle basit ve hızlı olması sebebiyle kimyasal analiz sonuçlarıla kontrol edilmektedir. Ancak, kimyasal analizin mineral içeriğini her zaman doğru tanımlayamaması, yapı-doku ve serbestleșmeye ait bilgi içermemesi nedeniyle cevher hazırlama süreçlerinin yorumlanmasında yetersiz kaldığı görülmektedir. Bu nedenle proses mineraloji verileri, özellikle tesis ișleyișini kararlı tutmak, üretim sırasında meydana gelebilecek olası değișikliklerin etkilerini ve hatta uzun süreli olarak tesis performansını kontrol etmek için oldukça değerli bilgiler sunmaktadır (Sutherland, 1998a ve b).

Bu çalıșmada, proses mineralojisinden elde edilen bilgiler ile altın içeren sülfürlü bakır cevherinin zenginleștirildiği bir flotasyon tesisinin performans değerlendirilmesi yapılarak, proses mineralojisinin bu tür çalıșmalarda kullanımına yönelik değerlendirmeler yapılmıștır. Bu çalıșma genel bir sonuç çıkarmaktan öte, cevherin flotasyon davranımının detaylı mineralojik verilerle nasıl yorumlanabileceğini ve gelecekte yapılacak çalıșmalar için bu yaklașımın nasıl kullanılacağını ifade etmektedir. Bu kapsamda, tesis beslemesi, bakır (Cu) konsantresi, pirit (Py) konsantresi ve bakır süpürme artığındaki minerallerin tanımlanması, serbestleșme durumları ve bağlı tanelerdeki mineral birliktelikleri tane boyu bazında detaylı analiz edilerek hem sülfürlü mineral hem de altın davranımı prosesle ilișkilendirilmiștir.

\section{MALZEME ve YÖNTEM}

Çalışma kapsamında, tesisinin flotasyon beslemesinden, bakır ve pirit konsantrelerinden ve Cu flotasyon süpürme artığı akıșlarından elde edilen numuneler kullanımıștır. Bu akıșlardan alınan numuneler, tesisin kararlı çalıștığı durumda yapılan örnekleme çalıșmasıyla elde edilmiștir. Çalıșmada izlenen yöntem, seçilen akıșların detaylı mineralojik karakterizasyonu ve metalurjisinin birlikte değerlendirilmesini içermektedir. Tüm proses mineraloji verileri, tonaj, metal içerikleri ve ana minerallerin verimleri gibi madde denkliği değerleri, tesis performansının değerlendirilmesi için kullanılmıștır. Bu bağlamda, incelenmek üzere seçilen akıșlar tesisteki problemlerin tanımlanması ve yapılacak iyileștirmenin potansiyel önemine göre belirlenmiștir. Dolayısıyla, bakır ve altının kaybı, bakır konsantresinin gang mineralleri tarafından kirletilmesinin olası nedenleri değerlendirilebilmiștir. Buna dayanarak, flotasyon beslemesi, Cu konsantre ve $\mathrm{Cu}$ süpürme artığındaki sülfürlü minerallerin tane boyu bazındaki serbestleșme verileri Clemex Vision PE 5.0 otomatik görüntü analiz sistemi ile belirlenmiștir. Mineralojik karakterizasyonun temel amacı, bakır minerallerinin, sülfürlü ve sülfürlü olmayan gang minerallerinin (NSG: non-sulphide gangue) ve bağı tanelerdeki mineral birlikteliklerinin türü ve serbestleșme durumlarını belirlemektir. Bu amaçla, incelenen akıșlardaki numunelerin dar tane boyu aralığında 
parlak kesitleri hazırlanmıștır. Bunun için farklı keçe ve incelikteki elmas solüsyonlarla așındırma ve parlatma yapabilen Struers marka kesit parlatma cihazı kullanılmıștır.

Numune alınan noktaları da gösteren flotasyon devresinin basitleștirilmiș akım șeması Șekil 1'de gösterilmektedir. Buna göre, sülfürlü mineraller öncelikle toplu olarak yüzdürülmekte, sonrasında bakır ve pirit için seçimli flotasyon uygulanmaktadır. Cu süpürme artığı akıșı, hem Cu devresinin artığı hem de pirit devresinin beslemesi olması açısından önemlidir.

Şekil 1'de belirtilen numune alma noktalarının yanısıra Cu devresindeki bazı önemli akıșların da tonaj ve tenör bilgisi flotasyon devrelerinin kararlı olduğu koșul için tesis tarafından temin edilmiștir. Bu verilere göre akıșların tonaj, tenör ve verim değerleri JKSimFloat madde denkliği programı kullanılarak hesaplanmıștır (Çizelge 1).

Clemex Vision PE 5,0 otomatik optik görüntü analiz sistemi ile pirit (Py), sülfürlü olmayan gang mineralleri (NSG), enargit, tennantit, kalkopirit (Cp), bornit (Bor), galen (Gal) ve sfalerit (Sp) gibi akıșlardaki ana mineraller nicel olarak belirlenmiștir. Kalkozin ve kovellin gibi ikincil bakır mineralleri oldukça eser miktardadır. Bilindiği üzere optik sistemler minerallerin refleksiyon ve renk gibi optik özelliklerini baz alır. Enargit (Cu${ }_{3} \mathrm{AsS}_{4}$ : \%48,4 Cu, \%19,0 As ve \%32,5 S) ve tennantitin $\left((\mathrm{Cu}, \mathrm{Fe})_{12} \mathrm{As}_{4} \mathrm{~S}_{13}: \% 3,8 \mathrm{Fe}, \% 47,5 \mathrm{Cu}, \% 20,4 \mathrm{As}\right.$ ve $\% 28,3 \mathrm{~S})$ mikroskop altında parlak kesit renkleri oldukça benzer olduğu için birbirlerinden ayırt edilmesi oldukça zordur. Her iki mineral de bir Cu-As minerali olup konsantrede alınması gerektiği için çaıșmada bu mineraller tek bir grup olarak tanımlanmıș ve E\&T olarak kodlanmıștır. Ana minerallerin ağırlık bazında yüzde miktarını ifade eden modal analizi, serbestleșme durumları ve ikili ve çoklu bağlı tane miktarları dar tane boyu fraksiyonlarında nicel olarak belirlenmiștir.

Çalışmada, sülfürlü minerallere ek olarak cevherin altın içeriğinden dolayı altın davranımının da incelemesi yapılmıș, özellikle bakır ve pirit konsantrelerindeki altın fazlarının ve birlikteliklerinin tanımı Activation Laboratories'de (Kanada) bulunan QemSCAN cihazı kullanılarak gerçekleștirilmiștir. QemSCAN, optik sistemlerden farklı olarak kimyasal analiz hassasiyetinde mineral tanımlama ve nicel serbestleșme analizi yapan, bir yazılımla donatılmıș otomatik bir taramalı elektron mikroskobudur.

\section{SONUÇLAR ve TARTIȘMA}

\section{Mineralojik Karakterizasyon}

Ekonomik öğütme boyunda elde edilen serbestleșme derecesi tüm zenginleştirme işlemlerinin başarısı için çok önemli bir parametredir; dolayısıyla özellikle tane boyu bazında hesaplanan serbestleșme dereceleri öğütmenin yeterli olup olmadığı hakkında fikir vermektedir. Buna göre ana bakır mineralleri olan enargit ve tennantitin (E\&T) incelenen akıșlardaki serbestleșme derecelerini gösteren grafik Șekil 2'de verilmektedir.

Flotasyon beslemesinde E\&T minerallerinin $-45 \mu \mathrm{m}$ boyunda ancak \%60 serbestleșme derecesine sahip olduğu görülmekte, daha yüksek serbestleșme sağlanabilmesi için daha ince öğütmenin gerekliliği ortaya çıkmaktadır. Tesisin mevcut ișleyișinde, flotasyon beslemesinde toplam malzemenin \%70'i ve Cu metalinin ise \%92,7'si -90 $\mu \mathrm{m}$ tane boyundadır. Bakır konsantresinde de serbest E\&T taneleri $-45 \mu \mathrm{m}$ boyunda bulunmaktadır. Bakır süpürme artığında ise açıkça görüleceği gibi E\&T mineralleri genellikle bağlı formdadır. Serbest taneler ancak en ince boyda görülmektedir.

Tesisteki problemlerin tanımı için nasıl ki sadece kimyasal analiz verileri yeterli değilse, serbestleșme derecesi verisi de minerallerin bağlılık formları bilinmeden özellikle çözüm aşamasında yeterli olmamaktadır. Bu nedenle $\mathrm{Cu}$ devresinde numune alınan akıșlar bazında detaylı yapılan mineralojik karakterizasyon çalışmaları așağıda verilmektedir.

\section{Flotasyon beslemesi}

Flotasyon besleme akıșından alınan bu numune $+180 \mu \mathrm{m},-180+90 \mu \mathrm{m},-90+45 \mu \mathrm{m},-45+20 \mu \mathrm{m}$ ve $-20 \mu \mathrm{m}$ dar tane boyu fraksiyonlarına elenip parlak kesitleri hazırlanmıștır. Numune \%1,1 Cu, \%15,3 S, $\% 0,1 \mathrm{~Pb}, \% 0,2 \mathrm{Zn}, \% 12,4 \mathrm{Fe}$ ve \%0,3 As içermektedir. Tesisin mevcut ișleyișinde, flotasyon beslemesinin \%70'i, beslemedeki Cu metalinin ise \%92,7'si -90 $\mu \mathrm{m}$ tane boyundadır. Kimyasal analizler fraksiyonel bazda da yapılmıș olup sonuçlar Çizelge 2'de ağırık yüzdeleri ile birlikte verilmiștir. Clemex Vision görüntü analiz sistemi ile incelenen parlak kesitlerden ana minerallerin miktarını ifade eden modal analiz hesaplanmıș, sonuçlar Çizelge 3'te verilmiștir. Beslemenin tesis verilerine göre kimyasal analiz baz alınarak yapılan madde denkliği hesabında belirlenen Cu içeriği 


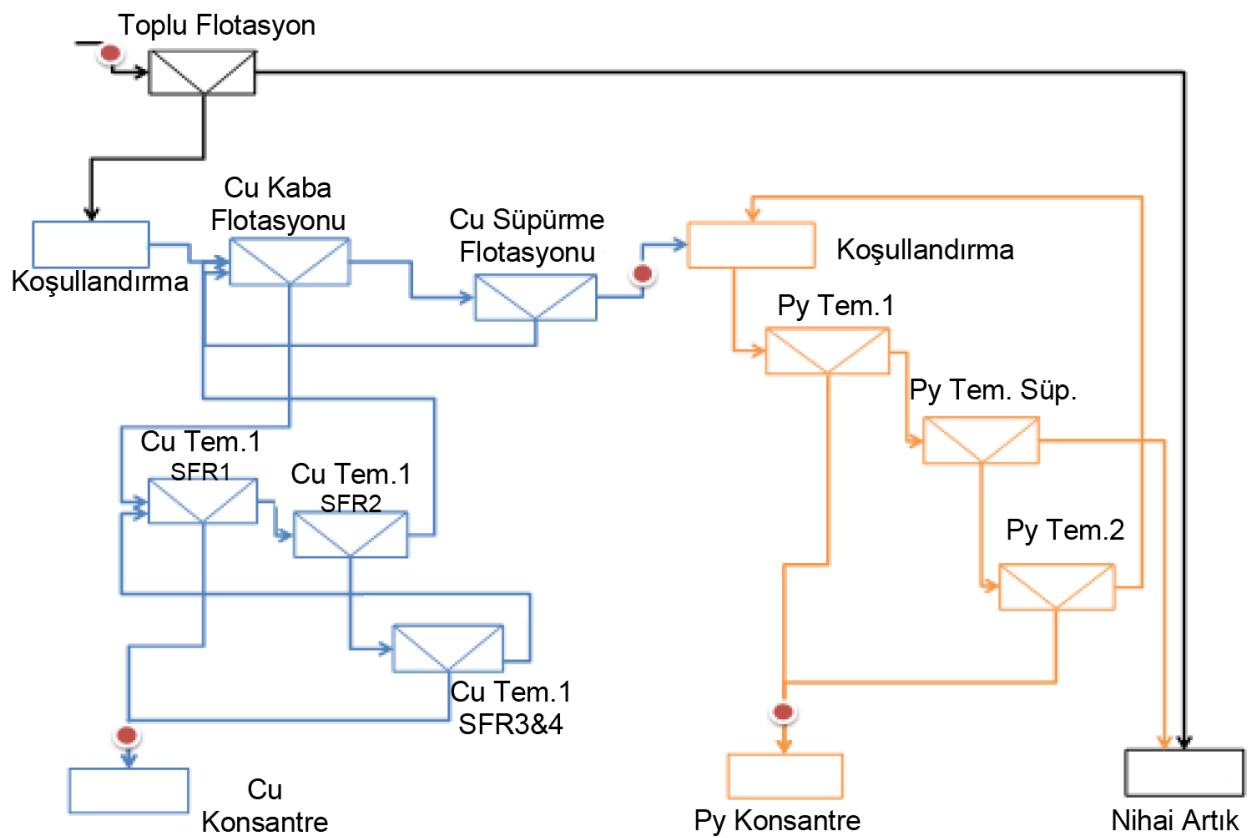

Şekil 1. Bakır ve pirit flotasyon devreleri ve numune alma noktaları.

Figure 1. Copper and pyrite flotation circuits and sampling points.

Çizelge 1. Madde denkliği sonucu hesaplanan tonaj, Cu tenör ve verim değerleri.

Table 1. Tonnage, $\mathrm{Cu}$ grade and recovery values calculated by mass balance.

\begin{tabular}{|c|c|c|c|}
\hline Akıșlar & Tonaj, t/s & $\mathrm{Cu}, \%$ & Cu Verim, \% \\
\hline Flotasyon Beslemesi & 265,00 & 1,09 & 100,00 \\
\hline Toplu Flotasyon Konsantresi & 65,36 & 4,07 & 92,36 \\
\hline Toplu Flotasyon Artığı & 199,64 & 0,11 & 7,62 \\
\hline Cu Kaba Flotasyon Konsantresi & 71,33 & 7,69 & 190,29 \\
\hline Cu Kaba Flotasyon Artığı & 96,66 & 1,50 & 50,32 \\
\hline Cu Süpürme Konsantresi & 45,79 & 2,50 & 39,73 \\
\hline Cu Süpürme Artığı & 50,87 & 0,60 & 10,59 \\
\hline Cu Konsantresi & 14,49 & 16,27 & 81,78 \\
\hline Nihai Artık & 250,51 & 0,21 & 18,22 \\
\hline
\end{tabular}

ile mineralojik verilerden geri hesaplama sonucu elde edilen $\mathrm{Cu}$ değeri neredeyse aynı $(\sim 1,1)$ olup mineralojik analizle kimyasal analizin oldukça uyumlu sonuçlar verdiği görülmektedir. Diğer bir deyișle, kimyasal ve mineralojik analiz uyumluluğu, Clemex Vision sistemiyle mineral tanımlama ve ölçümlerin yüksek doğrulukta yapıldığını desteklemektedir.
Mineral miktarlarının yanı sıra, bu minerallerin serbest, ikili ve çoklu bağlı formları da Clemex sistemi ile ölçülmüş, fraksiyonların ağırlıkları oranında Şekil 3'deki gibi grafiklendirilmiştir. Fraksiyonel bazdaki bağlı tane sınıfları, miktarca yüksek serbest piritin diğer bağlı tane miktarlarını maskelemesi nedeniyle serbest piritli (a) ve serbest pirit içermeyen (b) 


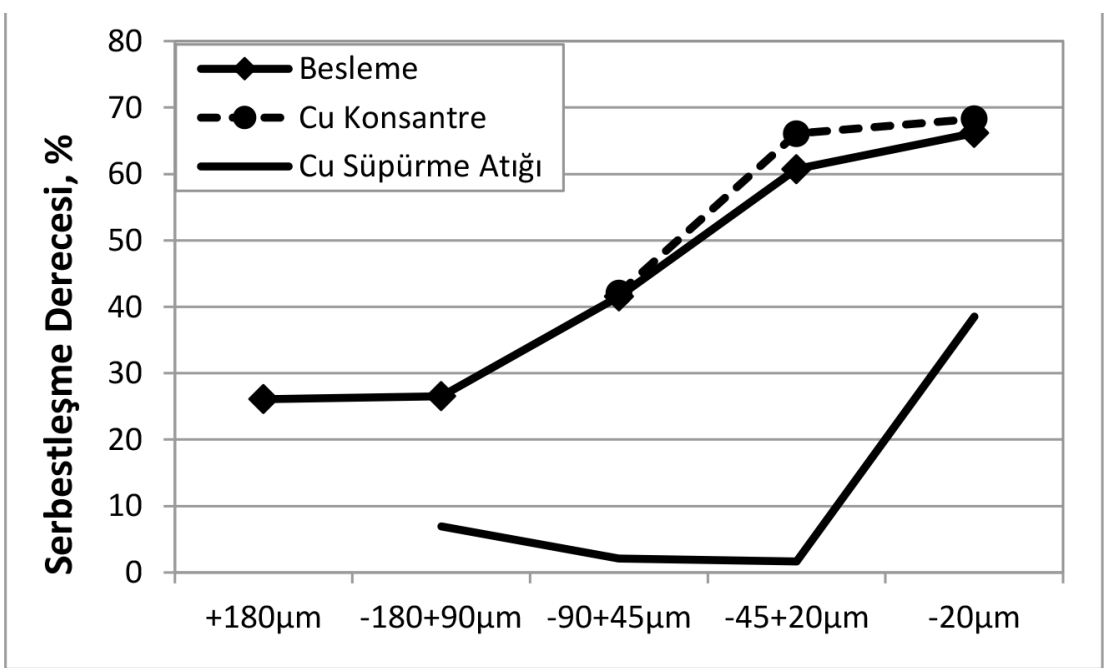

Şekil 2. Numune alınan akışlardaki Cu minerallerinin serbestleșme dereceleri.

Figure 2. Liberation degrees of $\mathrm{Cu}$ minerals in sampled streams.

olmak üzere iki șekilde sunulmuștur. Çizelge 3'te de görüldüğü gibi $\mathrm{Cu}$ minerallerinin önemli miktarının $-90 \mu m$ tane boyunda olması, beklendiği üzere bağlı tanelerinin de bu boyun altında yoğunlaștığını göstermektedir. E\&T mineralleri beslemede hem serbest $(\% 0,2-0,8)$ hem de ikili ve çoklu bağlı tane formunda bulunmaktadır. E\&T mineralleri genellikle pirit ve NSG mineralleri ile bağlı olup en ince fraksiyon olan $-20 \mu$ m'da bile gözlenmektedir.

E\&T minerallerinin bağlı tanelerdeki kenetlenme miktarı Çizelge 4'te verilmekte olup bu veriler aynı zamanda E\&T minerallerinin bağlı bir tane içinde nasıl dağıldığını göstermekte ve serbestleșme boyunu ișaret etmektedir. Örneğin, E\&T minerallerinin \%60,8'i -45+20um fraksiyonunda ve \%100-95 serbestleșme sınıfındadır. İlgili çizelge E\&T minerallerinin \%80'den fazlasının $-90 \mu \mathrm{m}$ boyunda ve $>\% 50$ serbestleșme sınıfında olduğunu göstermektedir. Bu durum, kaba flotasyon așaması ve konsantre tenörünün önemli bir sorun olmadığı koșul için kabul edilebilirdir. E\&T mineralleri \%30-15 gibi daha düșük serbestleșme sınıflarında ince boylara göre daha yoğun görülmektedir. E\&T minerallerinin daha düșük alan yüzdesine sahip olduğu böyle bağlı tanelerin toplu flotasyon artığında kaybedilme olasılığı yüksektir.

\section{Cu konsantre}

Bakır konsantresi de flotasyon beslemesi gibi 5 fraksiyondan olușmaktadır ancak, $+180 \mu \mathrm{m}$ ve $-180+90 \mu \mathrm{m}$ fraksiyonlarında oldukça az malzeme kalması nedeniyle mineralojik analiz bu iki fraksiyona uygulanmamıștır. Fraksiyonel bazda yapılan kimyasal analize göre toplamdaki tenör değerleri \%15,9 $\mathrm{Cu}, \% 43,3 \mathrm{~S}, \% 1,4 \mathrm{~Pb}, \% 2,92 \mathrm{Zn}, \% 25,8 \mathrm{Fe}$ ve \%4,9 As'dir (Çizelge 5). Galen ve sfaleritin de bir miktar konsantreye geldiği görülmektedir. Fe içeriğinin ana kaynağının pirit olduğu da Çizelge 6'da verilen modal analizden anlaşılmaktadır.

Cu konsantresinin modal mineralojik analiz sonucuna göre, E\&T mineralleri fraksiyonlarda yakın miktarlarda dağılmakta, diğer önemli $\mathrm{Cu}$ minerali olan kalkopirit ise \%2-3,1 civarında bulunmaktadır. Tüm $\mathrm{Cu}$ minerallerinin serbest ve bağlı formdaki fraksiyonel dağılımı Șekil 4'de grafiklendirilmiștir.

Șekil 4'te verilen üç boyutlu grafiğe göre, serbest E\&T minerallerinin miktarı fraksiyonlar içinde \%1,27,3 arasında değișmektedir. Bağlı formda olan E\&T taneleri ise genellikle piritle $-45 \mu \mathrm{m}$ boyutunda ve NSG mineralleri ile daha iri boylarda kenetlenme göstermektedir. İncelenen 3 fraksiyonda da serbest pirit miktarı dikkat çekicidir. Serbest pirit \%3,7-22 oranında görülmekte özellikle ince boylarda bir miktar artıș eğiliminde olmaktadır. Özellikle en ince boy olan -20um'de serbest piritin konsantrede kazanım mekanizması için suyla tașınımdan söz edilebilir. Literatürdeki pek çok araștırma serbest gang tanelerinin $45 \mu$ m'den irilerinin konsantreye ancak gerçek flotasyonla kazanılacağını ifade etmektedir. Șekilden de görüldüğü üzere $45 \mu \mathrm{m}$ 'den iri fraksiyonda yaklașık \%5 kadar serbest pirit bulunmaktadır. Bu durum, bu tanelerin konsantreye gerçek flotasyonla kazanıldı- 
Çizelge 2. Flotasyon beslemesinin fraksiyonel kimyasal analizi.

Table 2. Chemical anaylsis of flotation feed on size basis.

\begin{tabular}{cccccccc}
\hline & Ağırlık, \% & $\mathbf{C u}, \%$ & $\mathbf{S}, \%$ & $\mathbf{P b}, \%$ & $\mathbf{Z n ,} \%$ & $\mathbf{F e}, \%$ & As, \% \\
\hline$+180 \mu \mathrm{m}$ & 7,88 & 0,11 & 4,52 & 0,012 & 0,02 & 3,85 & 0,06 \\
$-180+90 \mu \mathrm{m}$ & 20,25 & 0,35 & 7,96 & 0,027 & 0,10 & 6,40 & 0,13 \\
$-90+45 \mu \mathrm{m}$ & 20,70 & 1,25 & 19,82 & 0,079 & 0,24 & 15,30 & 0,33 \\
$-45+20 \mu \mathrm{m}$ & 15,31 & 1,48 & 23,90 & 0,115 & 0,24 & 19,50 & 0,39 \\
$-20 \mu \mathrm{m}$ & 35,86 & 1,52 & 15,44 & 0,15 & 0,20 & 12,94 & 0,47 \\
Toplam & 100,00 & 1,11 & 15,27 & 0,10 & 0,18 & 12,39 & 0,33 \\
\hline
\end{tabular}

Çizelge 3. Flotasyon beslemesinin fraksiyonel modal mineralojik analizi.

Table 3. Modal mineralogical analysis of flotation feed on size basis.

\begin{tabular}{ccccccccc}
\hline & Cp & Sp & Py & Gal & Bor & NSG & E\&T & Toplam \\
\hline$+180 \mu \mathrm{m}$ & 0,00 & 0,00 & 2,24 & 0,00 & 0,00 & 97,45 & 0,30 & 100,00 \\
$-180+90 \mu \mathrm{m}$ & 0,08 & 0,10 & 7,57 & 0,00 & 0,00 & 91,70 & 0,55 & 100,00 \\
$-90+45 \mu \mathrm{m}$ & 0,17 & 0,45 & 34,16 & 0,00 & 0,00 & 62,52 & 2,71 & 100,00 \\
$-45+20 \mu \mathrm{m}$ & 0,42 & 0,72 & 33,51 & 0,07 & 0,13 & 62,72 & 2,43 & 100,00 \\
$-20 \mu \mathrm{m}$ & 0,36 & 0,31 & 29,98 & 0,08 & 0,06 & 66,01 & 3,20 & 100,00 \\
\hline
\end{tabular}

ğını ve dolayısıyla tesisteki flotasyon kimyasının çok uygun olmadığını ișaret etmektedir. Flotasyon tesisinde, toplayıcı olarak Potasyum Amil Ksantat (PAX) pH 12 değerinde kullanılmaktadır. PAX sülfürlü mineral flotasyonunda iyi bilinen kuvvetli bir toplayıcı olup özellikle sülfürlü mineraller arasında seçimliliğin ön planda olmadığı toplu flotasyon koșullarında genellikle tercih edilmektedir. Dolayısıyla, pirit tanelerinin gerçek flotasyonla konsantrede kazanılmasında en önemli nedenin PAX olabileceği öngörülebilir. Buna ek olarak, su kimyası ve özellikle Ca iyonlarının varlığı da dikkate alınmalıdır. Çünkü, Ca iyonlarının hidroksil bileșikleri yüksek pH değerinde sülfür minerallerinin yüzey elektrik yüklerini tersine çevirebilmekte ve anyonik karakterdeki PAX iyonları elektrostatik etkileșim yoluyla mineral yüzeyine soğurulabilmektedir.

E\&T mineralleri ile kalkopiritin $\mathrm{Cu}$ konsantresindeki bağlı taneler içindeki dağılımı Çizelge 7'de verilmektedir. Daha serbest E\&T minerallerinin $-45 \mu \mathrm{m}$ boyunda olduğu ancak, daha az serbestleșme sınıfını tem- sil eden \%95-50 aralı̆̆ında ise önemli miktarda bu minerallerin dağıldığı görülmektedir. Serbestleșme sınıfının $<\% 30$ aralığında ise flotasyon beslemesine oranla daha az miktarda tane olduğu görülmektedir. Bu da toplu flotasyon așamasında, bu sınıftaki bağlı tanelerin kaybedildiği șeklinde yorumlanabilir. Toplu flotasyon artığının fraksiyonel kimyasal ve mineralojik analizi ile bu durum daha açık bir șekilde ortaya konulmalıdır. Kalkopiritin ise konsantreye hem serbest hem de bağlı tanelerinin kazanıldığı görülmektedir.

\section{Cu süpürme artığı}

Cu süpürme artığı da diğer iki akıș numunesi gibi 5 fraksiyonda elenmiș ancak $+180 \mu \mathrm{m}$ fraksiyonunda analiz yapacak kadar numune kalmamıștır. Fraksiyonel bazda yapılan kimyasal analiz sonuçları Çizelge 8'de verilmektedir. Akıșın Cu tenörü 0,8 olup fraksiyon ağırlıkları göz önüne alındığında bakırın \% 45 'inin $20 \mu m$ 'den daha ince boyda kaybedildiği görülmektedir. 


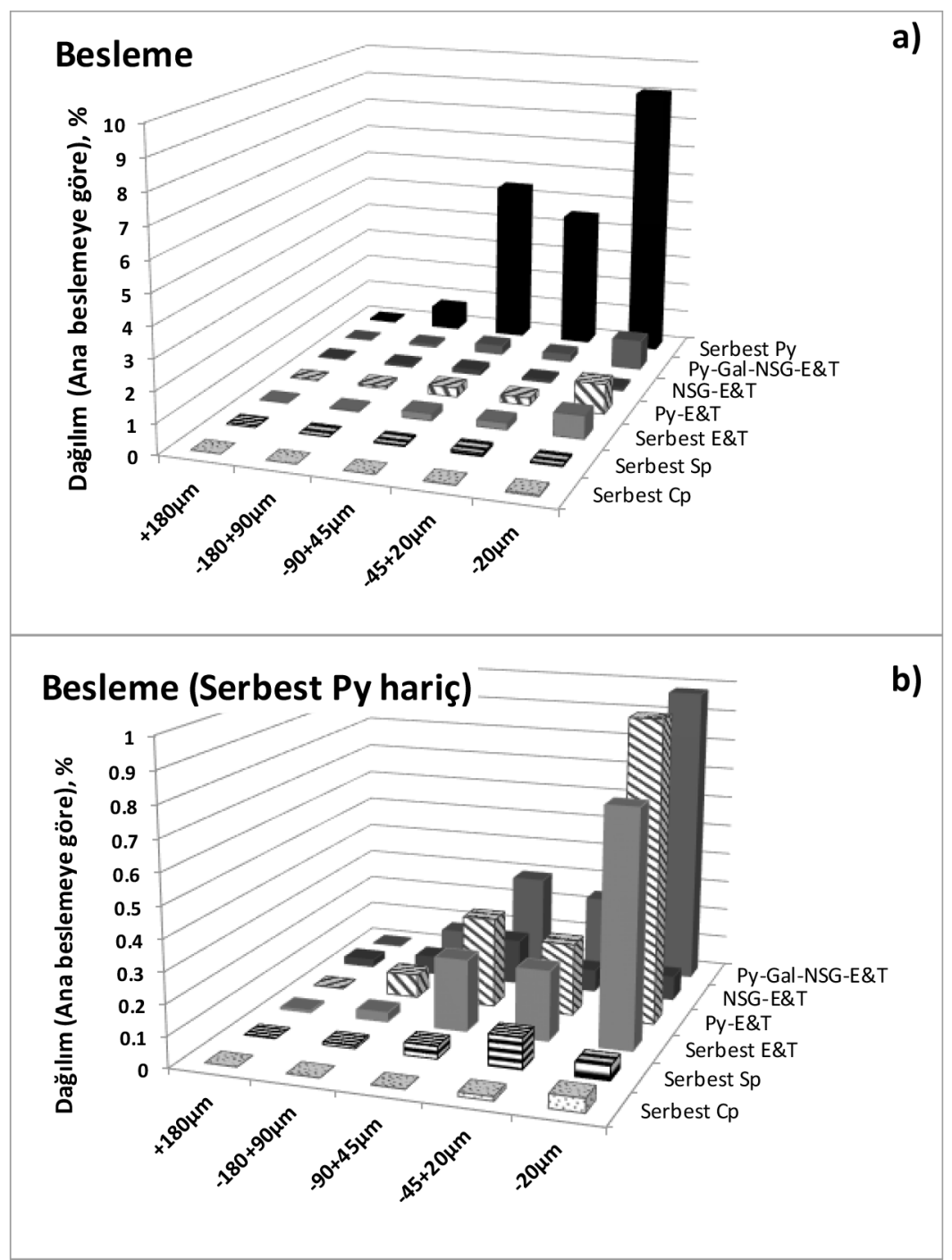

Şekil 3. Flotasyon beslemesinin fraksiyonel bazda serbest ve bağlı tane dağılımı a) besleme b) besleme (serbest Py hariç).

Figure 3. Distribution of free and binary particles of flotation feed on size basis a) feed b) feed (except free Py).

Çizelge 4. Flotasyon beslemesinde E\&T minerallerinin serbestleşme sınıflarına dağııımı.

Table 4. Distribution of E\&T minerals to liberation classes in flotation feed.

\begin{tabular}{cccccccccc}
\hline \multicolumn{7}{c}{ Serbestleșme Sınıfları, \% } \\
\hline & $100-95$ & $95-75$ & $75-50$ & $50-30$ & $30-15$ & $15-5$ & $5-0$ & Toplam \\
\hline$+180 \mu \mathrm{m}$ & 25,96 & 41,02 & 14,03 & 0,17 & 0,26 & 10,48 & 8,09 & 100,00 \\
$-180+90 \mu \mathrm{m}$ & 26,70 & 20,98 & 15,06 & 8,66 & 13,14 & 6,22 & 9,23 & 100,00 & 100,00 \\
$-90+45 \mu \mathrm{m}$ & 38,42 & 24,69 & 19,64 & 5,42 & 5,51 & 3,14 & 3,18 & 3,13 & 100,00 \\
$-45+20 \mu \mathrm{m}$ & 60,81 & 11,91 & 13,42 & 2,60 & 3,67 & 4,46 & 3,10 \\
$-20 \mu \mathrm{m}$ & 64,83 & 13,56 & 7,30 & 2,68 & 3,75 & 5,78 & 2,10 & 100,00 \\
\hline
\end{tabular}


Çizelge 5. Cu konsantresinin fraksiyonel kimyasal analizi.

Table 5. Chemical analysis of Cu concentrate on size basis.

\begin{tabular}{cccccccc}
\hline & Ağılık, \% & $\mathbf{C u} \%$ & $\mathbf{S}, \%$ & $\mathrm{~Pb}, \%$ & $\mathrm{Zn}, \%$ & $\mathrm{Fe}, \%$ & As, \% \\
\hline$+180 \mu \mathrm{m}$ & 0,25 & - & - & - & - & - & - \\
$-180+90 \mu \mathrm{m}$ & 3,89 & 16,05 & 35,50 & 0,70 & 6,02 & 18,92 & 5,32 \\
$-90+45 \mu \mathrm{m}$ & 23,27 & 15,21 & 43,43 & 1,49 & 3,32 & 24,95 & 4,79 \\
$-45+20 \mu \mathrm{m}$ & 24,18 & 12,66 & 46,74 & 1,47 & 2,25 & 29,00 & 4,01 \\
$-20 \mu \mathrm{m}$ & 48,41 & 17,93 & 42,34 & 1,44 & 2,84 & 25,34 & 5,57 \\
Toplam & 100,00 & 15,91 & 43,29 & 1,42 & 2,92 & 25,82 & 4,99 \\
\hline
\end{tabular}

Cizelge 6. Cu konsantresinin fraksiyonel modal mineralojik analizi.

Table 6. Modal mineralogical analysis of Cu concentrate on size basis.

\begin{tabular}{ccccccccc}
\hline & $\mathbf{C p}$ & $\mathbf{S p}$ & $\mathbf{P y}$ & Gal & Bor & NSG & E\&T & Toplam \\
\hline$-90+45 \mu \mathrm{m}$ & 2,24 & 3,49 & 46,98 & 0,30 & 0,57 & 23,23 & 23,19 & 100,00 \\
$-45+20 \mu \mathrm{m}$ & 3,11 & 1,88 & 63,28 & 0,56 & 0,58 & 7,04 & 23,54 & 100,00 \\
$-20 \mu \mathrm{m}$ & 2,36 & 1,99 & 62,87 & 0,44 & 0,49 & 6,81 & 25,04 & 100,00 \\
\hline
\end{tabular}

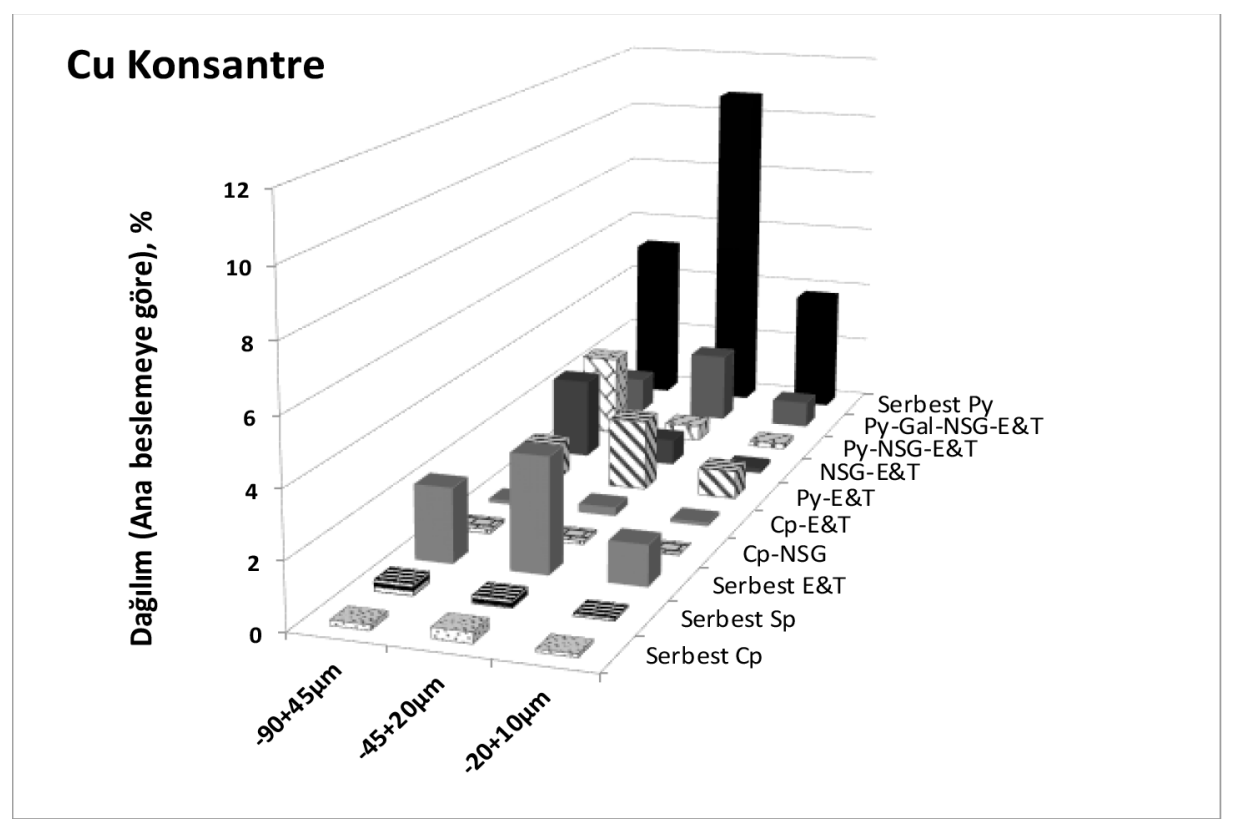

Şekil 4. Cu konsantresinin fraksiyonel bazda serbest ve bağlı tane dağılımı.

Figure 4. Distribution of free and binary particles of $\mathrm{Cu}$ concentrate on size basis. 
Çizelge 7. Cu konsantresinde E\&T ve kalkopirit minerallerinin serbestleșme sınıflarına dağııımı.

Table 7. Distribution of E\&T and chalcopyrite minerals to liberation classes in Cu concentrate.

\begin{tabular}{ccccccccc}
\hline \multicolumn{7}{c}{ Serbestleșme Sınıfları, \% } \\
\hline Enargit\&Tennantit & $\mathbf{1 0 0 - 9 5}$ & $\mathbf{9 5 - 7 5}$ & $\mathbf{7 5 - 5 0}$ & $\mathbf{5 0 - 3 0}$ & $\mathbf{3 0 - 1 5}$ & $\mathbf{1 5 - 5}$ & $\mathbf{5 - 0}$ & Toplam \\
\hline$-90+45 \mu \mathrm{m}$ & 40,66 & 25,13 & 14,85 & 9,56 & 6,31 & 2,43 & 1,06 & 100,00 \\
$-45+20 \mu \mathrm{m}$ & 63,85 & 14,32 & 10,20 & 5,33 & 2,52 & 2,37 & 1,41 & 100,00 \\
$-20+10 \mu \mathrm{m}$ & 67,76 & 11,68 & 9,15 & 5,89 & 3,30 & 1,66 & 0,57 & 100,00 \\
\hline CU CONC & & & Liberation Classes, \% & & & \\
\hline Kalkopirit & $100-95$ & $95-75$ & $75-50$ & $50-30$ & $30-15$ & $15-5$ & $5-0$ & Toplam \\
\hline$-90+45 \mu \mathrm{m}$ & 30,83 & 23,24 & 18,82 & 5,94 & 12,75 & 7,03 & 1,38 & 100,00 \\
$-45+20 \mu \mathrm{m}$ & 45,67 & 17,28 & 19,32 & 8,53 & 6,01 & 2,76 & 0,44 & 100,00 \\
$-20+10 \mu \mathrm{m}$ & 46,35 & 14,78 & 18,78 & 11,89 & 5,05 & 2,41 & 0,75 & 100,00 \\
\hline
\end{tabular}

Çizelge 9'da verilen modal mineralojik analiz sonuçları ise, kalkopirit gibi diğer majör Cu mineral miktarının bu akıșta inmal edilebilir oranda düșük olduğu için asıl Cu kaybının E\&T minerallerinden kaynaklandığını ișaret etmektedir.

Artıktaki Cu kaybının E\&T minerallerinden kaynaklandığının belirlemesi üzerine bu kayıpların serbest ya da bağlı tane gibi hangi formda olduğunu gösteren fraksiyonel bazda 3 boyutlu serbestleșme grafiği çizilmiștir (Șekil 5). Serbest E\&T mineralleri görüldüğü gibi sadece $-20 \mu \mathrm{m}$ tane boyundadır. $-45 \mu \mathrm{m}$ fraksiyonunun ağırlıkça oranının yüksek olması nedeniyle ikili ve çoklu bağlı tanelerin de bu boyun altında yoğunlaștığı görülmektedir. E\&T minerallerinin bu bağlı tane

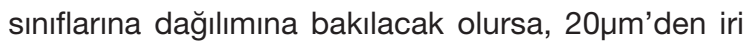
tanelerin çoğunun \%50'den daha düșük serbestleșme sınıflarında olduğu görülmektedir. Yüzde 75 ve üstündeki serbestleșme sınıflarında ise E\&T mineral-

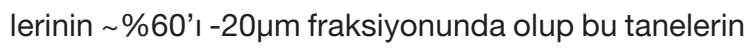
uygun flotasyon kimyası ve hidrodinamiğinin ayarlandığı koșullarda kazanııması mümkün olabilir. Ancak, 20um'den daha iri tanelerde serbestleșmeyi artırmak için ince öğütme gerekmektedir (Çizelge 10).

Çizelge 1'de verilen tesis ölçüm bazlı madde denkliği sonuçlarına göre, Cu süpürme artığının tonajı 50,9 $\mathrm{t} / \mathrm{s}$, Cu tenörü ve verimi ise sırasıyla $\% 0,6$ ve $\% 10,6$ olarak hesaplanmıștır. Fraksiyonel yapılan kimyasal analiz sonuçlarına göre ise bu akıșın ortalama tenörü \%0,8 Cu olarak ölçülmüștür. Tesisin akım șemasında (Șekil 1), Cu kaba flotasyon bankına Cu süpürme konsantresi ve SFR2 (Stage Flotation Reactor) temizleme artığının geri çevrildiği görülmektedir. Ancak geri dönen bu akıșlardaki Cu metal miktarı \%150 olup oldukça yüksektir. Cu süpürme artığındaki bakır kaybının önemli nedenlerinden biri olarak bu yüksek devreden yük miktarı dikkate alınmalıdır. Çizelge 11 'de toplam Cu metal kaybının $0,4 \mathrm{t} / \mathrm{s}$ olduğu ve bunun neredeyse yarısının $-20 \mu \mathrm{m}$ fraksiyonundan kaynaklandığı görülmektedir. Șekil 5 ve Çizelge 11 birlikte incelendiğinde, bakııın \%44,3'ünün bu fraksiyonda biriktiği ve E\&T mineral tanelerinin yaklașık \%60'ının serbest formda olduğu görülmektedir. Bu miktar flotasyon beslemesindeki \%2,8'lik kısma yani saatte $101 \mathrm{~kg}$ bakıra karșılık gelmektedir. Diğer tane boyu fraksiyonlarındaki bakır kaybı, pirit ve NSG mineralleri ile bağlılık durumundan kaynaklanmaktadır.

Cu süpürme artığının proses mineraloji verileri ile madde denkliğini içeren ilgili hesaplamalar, bakır verimini $\% 3$ oranında artırmanın mümkün olacağını göstermiștir. Bununla birlikte, ince tanelerin flotasyonunda karșılașılan zorluklardan literatürde pekçok araștırmada bahsedilmektedir. İnce tanelerin düșük kazanım değerleri için, yetersiz flotasyon süresi, sülfürlü minerallerin yüzey oksidasyonu ve uygun olmayan hücre dinamiği gibi olası nedenler öne sürülmektedir. Cu kaba ve süpürme banklarındaki toplam flotasyon süresi yaklașık 38 dakika olarak hesaplanmıș olup bu süre yaklașık \%4 Cu tenörlü (toplu flotasyon konsantresi) bir bakır cevherinin flotasyonu için yeterlidir. Dolayısıyla, problem așırı yüzey oksidasyonu 
Çizelge 8. Cu süpürme artığının fraksiyonel kimyasal analizi.

Table 8. Chemical analysis of Cu scavenger tail on size basis.

\begin{tabular}{cccccccc}
\hline & Ağırlık, \% & $\mathbf{C u} \%$ & $\mathbf{S}, \%$ & $\mathrm{~Pb}, \%$ & $\mathbf{Z n ,} \%$ & $\mathrm{Fe}, \%$ & As, \% \\
\hline$+180 \mu \mathrm{m}$ & 0,36 & - & - & - & - & - & - \\
$-180+90 \mu \mathrm{m}$ & 8,04 & 0,63 & 21,01 & 0,05 & 0,04 & 16,77 & 0,16 \\
$-90+45 \mu \mathrm{m}$ & 25,87 & 0,79 & 41,55 & 0,08 & 0,04 & 32,87 & 0,13 \\
$-45+20 \mu \mathrm{m}$ & 24,2 & 0,67 & 47,38 & 0,06 & 0,19 & 36,27 & 0,08 \\
$-20 \mu \mathrm{m}$ & 41,53 & 0,81 & 41,81 & 0,09 & 0,03 & 35,69 & 0,20 \\
Toplam & 100,00 & 0,75 & 41,27 & 0.08 & 0,07 & 33,45 & 0,15 \\
\hline
\end{tabular}

Çizelge 9. Cu süpürme artığının fraksiyonel modal mineralojik analizi.

Table 9. Modal mineralogical analysis of Cu scavenger tail on size basis.

\begin{tabular}{ccccccccc}
\hline & $\mathbf{C p}$ & $\mathbf{S p}$ & $\mathbf{P y}$ & Gal & Bor & NSG & E\&T & Toplam \\
\hline$-180+90 \mu \mathrm{m}$ & 0,01 & 0,01 & 20,83 & 0,00 & 0,00 & 78,84 & 0,30 & 100,00 \\
$-90+45 \mu \mathrm{m}$ & 0,02 & 0,02 & 60,44 & 0,00 & 0,00 & 39,21 & 0,30 & 100,00 \\
$-45+20 \mu \mathrm{m}$ & 0,01 & 0,06 & 82,35 & 0,01 & 0,00 & 17,25 & 0,32 & 100,00 \\
$-20 \mu \mathrm{m}$ & 0,01 & 0,05 & 80,02 & 0,00 & 0,02 & 19,44 & 0,46 & 100,00 \\
\hline
\end{tabular}

Çizelge 10. Cu süpürme artığında E\&T minerallerinin serbestleșme sınıflarına dağıımı.

Table 10. Distribution of E\&T minerals to liberation classes in Cu scavenger tail.

\begin{tabular}{cccccccccc}
\hline & \multicolumn{7}{c}{ Serbestleșme Sınıfları, \% } \\
\hline & $\mathbf{1 0 0 - 9 5}$ & $\mathbf{9 5 - 7 5}$ & $\mathbf{7 5 - 5 0}$ & $\mathbf{5 0 - 3 0}$ & $\mathbf{3 0 - 1 5}$ & $\mathbf{1 5 - 5}$ & $\mathbf{5 - 0}$ & Toplam \\
\hline$-180+90 \mu \mathrm{m}$ & 7,02 & 1,71 & 7,58 & 8,55 & 23,28 & 22,96 & 28,91 & 100,00 \\
$-90+45 \mu \mathrm{m}$ & 2,08 & 3,03 & 1,88 & 9,56 & 24,34 & 35,06 & 24,05 & 100,00 & 100,00 \\
$-45+20 \mu \mathrm{m}$ & 1,62 & 0,71 & 1,05 & 11,52 & 15,90 & 44,64 & 24,56 & 100 \\
$-20 \mu \mathrm{m}$ & 38,40 & 20,74 & 2,23 & 3,58 & 6,97 & 11,25 & 16,82 & 100,00 \\
\hline
\end{tabular}

ve/veya hücre dinamiğine bağlı olabilir. Madde denkliği hesaplamaları, Cu süpürme konsantresinden ve SFR2 artığından Cu kaba devresine gelen devreden yükün oldukça yüksek (yaklașık \%150) olduğunu göstermiștir. Yüksek devreden yük, aynı zamanda Cu süpürme artığından bakır kaybının ana nedenlerinden biri olarak görülmelidir.

\section{Bakır (Cu) ve Pirit (Py) Konsantrelerinde Altın (Au) Davranımı}

Bakır ve pirit konsantrelerinin mineralojik analizleri ActLab (Kanada)'da bulunan FEI QUANTA 650F model taramalı elektron mikroskopla ve özel bir yazılımla donatılmıș QemSCAN cihazıyla yapılmıștır. Özellikle altına yönelik analizde, 1 pikselin 1 mikron olduğu eser mineral tayini olarak adlandırılan SMS (Specific Mineral Search) modu kullanılmıștır. 


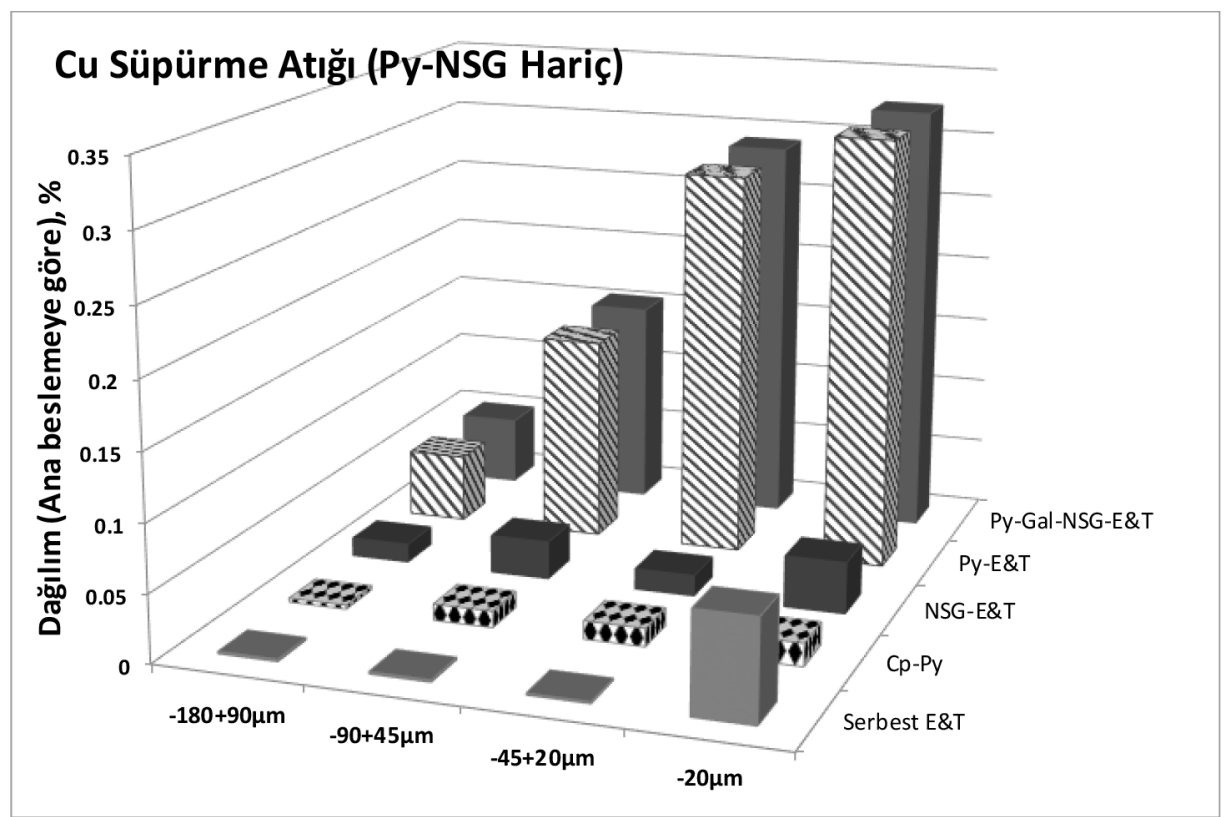

Şekil 5. Cu süpürme artığının fraksiyonel bazda serbest ve bağı tane dağııımı.

Figure 5. Distribution of free and binary particles of $\mathrm{Cu}$ scavenger tail on size basis.

Çizelge 11. Cu süpürme artığındaki malzeme ve Cu metal dağılımı.

Table 11. Distribution of material and Cu metal in Cu scavenger tail.

\begin{tabular}{cccccc}
\hline & Ağırlık, \% & Tonaj, t/s & $\mathbf{C u}, \%$ & $\mathbf{C u}, \mathbf{t} / \mathbf{s}$ & Cu dağıımı, \% \\
\hline$+180 \mu \mathrm{m}$ & 0,36 & 0,18 & - & - & - \\
$-180+90 \mu \mathrm{m}$ & 8,04 & 4,09 & 0,63 & 0,03 & 6,77 \\
$-90+45 \mu \mathrm{m}$ & 25,87 & 13,16 & 0,79 & 0,10 & 27,37 \\
$-45+20 \mu \mathrm{m}$ & 24,20 & 12,31 & 0,67 & 0,08 & 21,59 \\
$-20 \mu \mathrm{m}$ & 41,54 & 21,13 & 0,69 & 0,17 & 44,27 \\
Toplam & 100,00 & 50,87 & 0,75 & 0,38 & 100,00 \\
\hline
\end{tabular}

\section{Bakır konsantre}

Cu konsantresinde $-90+45 \mu \mathrm{m},-45+20 \mu \mathrm{m}$ ve -20 $\mu \mathrm{m}$ fraksiyonları analiz edilmiș, mineral miktarlarını ifade eden modal mineraloji ağırlık bazında Çizelge 12 'de sunulmuștur. Altın taneleri, nabit ve Au-Sb alașım formunda olmak üzere iki fazda görülürken, altının nabit formu özellikle $-90+45 \mu \mathrm{m}$ ve $-45+20 \mu \mathrm{m}$ fraksiyonlarında daha fazla dikkati çekmektedir. Altın için serbestleșme verisi serbest yüzey alanı cinsinden hesaplanmıștır. Serbest yüzey alanı ile tanımlanan serbestleșme verisi flotasyon açısından daha anlamlı olup ilgili mineralin tane yüzeyinde serbest olan kısmını ifade eder.

Nabit altın ve Au-Sb alașımın Çizelge 13'de sunulan serbestleșme verilerine göre, eğer altın tanelerinin serbest yüzey alanı \%10'dan küçükse o tane tamamen kenetli kabul edilmektedir. Eğer bu oran \%10-75 aralığında ise o tanenin diğer minerallerle belirli oranlarda birlikte bulunduğunu, $\% 75$ 'den fazla olduğunda ise o tanenin serbest kabul edileceğini ifade etmektedir. Buna göre, nabit altın $-45 \mu \mathrm{m}$ boyutlarında serbestleșme göstermekte, daha iri boyda 
Çizelge 12. Cu konsantresinin fraksiyonel modal mineraloji verileri.

Table 12. Modal mineralogy data of $\mathrm{Cu}$ concentrate on size basis.

\begin{tabular}{cccc}
\hline Tane Boyu & $\mathbf{- 9 0 + 4 5} \boldsymbol{\mu m}$ & $\mathbf{- 4 5 + 2 0 ~} \mathbf{m}$ & $\mathbf{- 2 0} \boldsymbol{\mu m}$ \\
\hline Nabit Altın & 0,028 & 0,024 & 0,009 \\
Au-Sb Alașım & 0,001 & 0,00 & 0,001 \\
Enargit & 23,68 & 18,65 & 20,85 \\
Tennantit & 0,18 & 0,15 & 0,07 \\
Kalkopirit & 3,31 & 2,84 & 7,17 \\
Altere Kalkopirit & 0,54 & 0,66 & 5,85 \\
Kalkopirit (As içeren) & 0,67 & 0,61 & 1,94 \\
Bornit & 0,92 & 0,86 & 0,75 \\
Pirit & 54,13 & 58,61 & 41,72 \\
Altere Pirit & 4,57 & 8,85 & 13,65 \\
Sfalerit & 3,75 & 2,25 & 2,11 \\
Kalkozin & 0,61 & 0,57 & 0,23 \\
Kovellin & 0,86 & 0,83 & 0,49 \\
Barit & 1,04 & 0,53 & 0,12 \\
Kuvars & 1,74 & 0,80 & 0,28 \\
Diğerleri & 3,97 & 3,77 & 4,76 \\
Toplam & 100,00 & 100,00 & 100,00 \\
\hline & & &
\end{tabular}

Çizelge 13. Cu konsantresindeki altın serbestleșme verileri.

Table 13. Gold liberation data in Cu concentrate.

\begin{tabular}{|c|c|c|c|c|c|c|}
\hline \multirow[b]{3}{*}{ Serbest Yüzey Alanı, \% } & \multicolumn{6}{|c|}{ Nabit Altın Serbestleșme Verileri } \\
\hline & \multirow{2}{*}{$\begin{array}{l}\text { Kenetli } \\
<=10\end{array}$} & & \multirow{2}{*}{$\begin{array}{l}\text { Bağlı } \\
20-50\end{array}$} & \multirow[b]{2}{*}{$50-75$} & \multicolumn{2}{|c|}{ Serbest } \\
\hline & & $10-20$ & & & $75-90$ & $90-100$ \\
\hline$-90+45 \mu \mathrm{m}$ & 100,00 & 0,00 & 0,00 & 0,00 & 0,00 & 0,00 \\
\hline$-45+20 \mu \mathrm{m}$ & 4,17 & 0,00 & 33,22 & 0,00 & 62,60 & 0,00 \\
\hline \multirow[t]{3}{*}{$-20 \mu \mathrm{m}$} & 7,85 & 47,65 & 0,04 & 0,25 & 0,00 & 44,21 \\
\hline & \multicolumn{4}{|c|}{ Au-Sb Serbestleșme Verileri } & & \\
\hline & \multicolumn{2}{|l|}{ Kenetli } & \multicolumn{2}{|l|}{ Bağlı } & \multicolumn{2}{|c|}{ Serbest } \\
\hline Serbest Yüzey Alanı, \% & $<=10$ & $10-20$ & $20-50$ & $50-75$ & $75-90$ & $90-100$ \\
\hline$-90+45 \mu \mathrm{m}$ & 100,00 & 0,00 & 0,00 & 0,00 & 0,00 & 0,00 \\
\hline$-45+20 \mu \mathrm{m}$ & 66,22 & 33,78 & 0,00 & 0,00 & 0,00 & 0,00 \\
\hline$-20 \mu \mathrm{m}$ & 28,32 & 4,06 & 6,68 & 56,96 & 0,17 & 3,80 \\
\hline
\end{tabular}


Çizelge 14. Cu konsantresindeki altının bağlılık durumu.

Table 14. Gold association in $\mathrm{Cu}$ concentrate.

\begin{tabular}{|c|c|c|c|c|c|c|}
\hline \multirow[t]{2}{*}{ Tane Boyu } & \multicolumn{2}{|c|}{$-20 \mu \mathrm{m}$} & \multicolumn{2}{|c|}{$-45+20 \mu \mathrm{m}$} & \multicolumn{2}{|c|}{$-90+45 \mu \mathrm{m}$} \\
\hline & $\begin{array}{l}\text { Nabit } \\
\text { Altın }\end{array}$ & Au-Sb Alașım & Nabit Altın & $\begin{array}{l}\text { Au-Sb } \\
\text { Alașım }\end{array}$ & Nabit Altın & $\begin{array}{l}\mathrm{Au}-\mathrm{Sb} \\
\text { Alașım }\end{array}$ \\
\hline Nabit Altın & 0,00 & 0,00 & 0,00 & 1,92 & 0,00 & 4,55 \\
\hline Au-Sb Alașım & 0,00 & 0,00 & 0,32 & 0,00 & 1,67 & 0,00 \\
\hline $\begin{array}{c}\text { Frayberjit } \\
\text { (düșük Fe-Sb_S az Ag) }\end{array}$ & 0,00 & 1,54 & 0,97 & 0,00 & 0,00 & 0,00 \\
\hline Enargit & 16,67 & 5,38 & 11,94 & 32,69 & 0,83 & 61,36 \\
\hline Kalkopirit & 0,00 & 3,08 & 5,48 & 0,00 & 0,00 & 2,27 \\
\hline Altere Kalkopirit & 5,56 & 0,00 & 0,97 & 0,00 & 0,83 & 11,36 \\
\hline Pirit & 52,78 & 59,23 & 30,32 & 51,92 & 95,00 & 20,45 \\
\hline Altere Pirit & 11,11 & 9,23 & 15,16 & 0,00 & 0,00 & 0,00 \\
\hline Galen & 0,00 & 0,00 & 3,23 & 0,00 & 0,00 & 0,00 \\
\hline Barit & 0,00 & 7,69 & 0,00 & 0,00 & 0,00 & 0,00 \\
\hline Matris & 13,89 & 13,85 & 28,39 & 13,46 & 0,83 & 0,00 \\
\hline
\end{tabular}
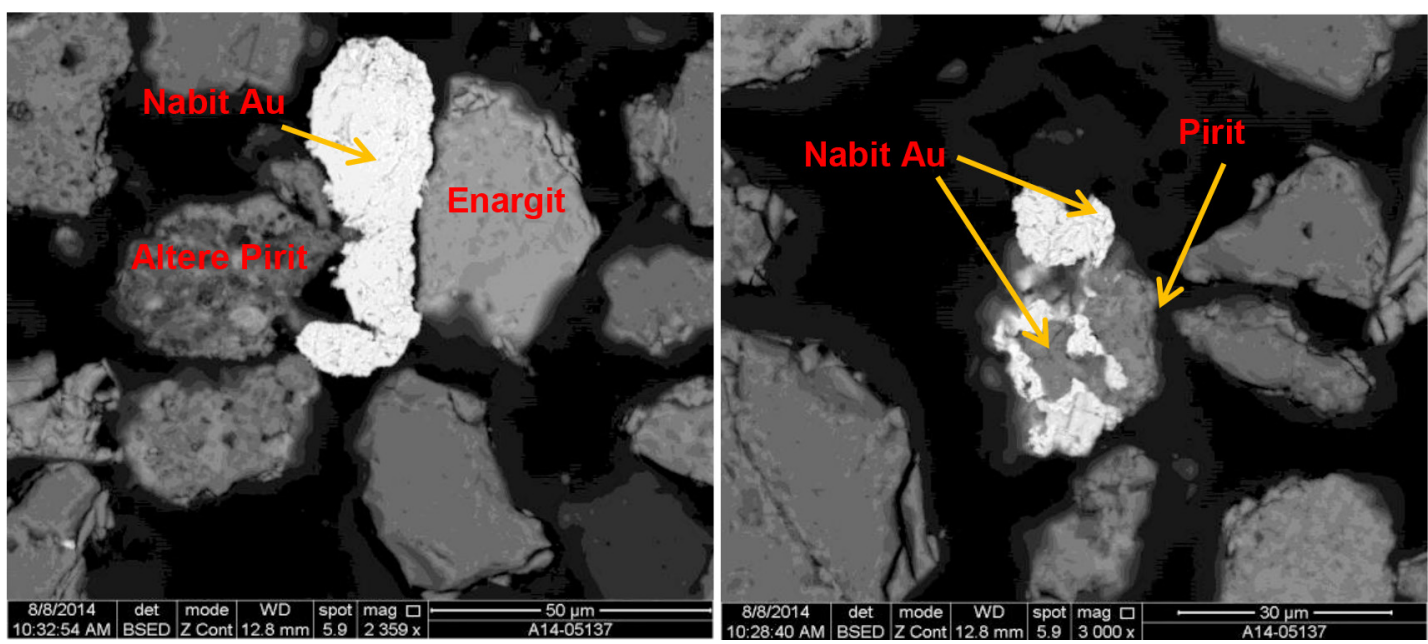

Şekil 6. Cu konsantresindeki altın tanelerinin BSE görüntüleri.

Figure 6. BSE images of gold grains in Cu concentrate.

ise kenetli formda bulunmaktadır. Au-Sb alașım taneleri ise çok daha az serbestleșmeye sahiptir.

Nabit altın ve Au-Sb tanelerinin hangi minerallerle bağlı olduğu bilgisi ise Çizelge 14'te verilmektedir. Nabit altın genellikle pirit, enargit ve altere piritle bağ- lı olup özellikle $+45 \mu$ m'da \%95'i piritle bulunmaktadır. Au-Sb alașım tanelerinin ise \%61,4'ü enargitle, $\% 20,5$ 'i ise piritle bağlıdır. İnce boylarda kompozit altın taneleri çoğunlukla pirit ve altere piritle birlikte bulunurken (\%45-60), geri kalan kısmı ise enargitle birliktelik göstermektedir. 
Çizelge 15. Py konsantresinin fraksiyonel modal mineraloji verileri.

Table 15. Modal mineralogy data of Py concentrate on size basis.

\begin{tabular}{|c|c|c|c|c|}
\hline Tane Boyu & $-180+90 \mu \mathrm{m}$ & $-90+45 \mu \mathrm{m}$ & $-45+20 \mu \mathrm{m}$ & $-20 \mu \mathrm{m}$ \\
\hline Nabit Altın & 0,01 & 0,00 & 0,00 & 0,00 \\
\hline Enargit & 0,75 & 0,33 & 0,09 & 0,11 \\
\hline Kalkopirit & 0,34 & 0,27 & 0,12 & 0,23 \\
\hline Altere Kalkopirit & 0,09 & 0,08 & 0,05 & 0,27 \\
\hline Kalkopirit (As içeren) & 0,11 & 0,08 & 0,04 & 0,09 \\
\hline Bornit & 0,04 & 0,01 & 0,00 & 0,00 \\
\hline Pirit & 62,40 & 82,78 & 82,86 & 64,84 \\
\hline Altere Pirit & 3,51 & 7,72 & 12,93 & 28,25 \\
\hline Pirotit & 0,15 & 0,21 & 0,34 & 0,10 \\
\hline Galen & 0,03 & 0,02 & 0,01 & 0,00 \\
\hline Barit & 0,35 & 0,22 & 0,09 & 0,02 \\
\hline Alunit & 0,01 & 0,01 & 0,00 & 0,00 \\
\hline Rutil & 0,09 & 0,05 & 0,03 & 0,01 \\
\hline Kuvars & 21,30 & 4,28 & 1,51 & 0,45 \\
\hline K-Feldspat & 0,07 & 0,02 & 0,01 & 0,00 \\
\hline Plajiyoklas & 0,69 & 0,14 & 0,05 & 0,01 \\
\hline Muskovit & 0,21 & 0,06 & 0,02 & 0,01 \\
\hline Kaolinit & 4,20 & 0,94 & 0,27 & 0,06 \\
\hline Pirofillit & 0,47 & 0,12 & 0,06 & 0,02 \\
\hline Pirit-Kil Karıșımı & 4,43 & 2,25 & 1,31 & 4,90 \\
\hline Diğerleri & 0,73 & 0,39 & 0,24 & 0,63 \\
\hline Toplam & 100,00 & 100,00 & 100,00 & 100,00 \\
\hline
\end{tabular}

Yapılan mineralojik analizde nabit altın tanelerinin \%80'inin 20 m'den daha küçük olduğu, Au-Sb tanelerinin ise daha ince boylarda olduğu tespit edilmiștir. Dolayısıyla, Cu konsantreden yerçekimiyle kazanılabilir altın (GRG-gravity recoverable gold) üretimi an- cak çok ince tane boyunda mümkün görünmektedir. Nabit altın tanelerinin diğer minerallerle olan bağlılı̆ı Șekil 6'da verilen geri saçınımlı elektron (BSE) görüntülerinden görülmektedir. 
Çizelge 16. Py konsantresindeki altının bağlıık durumu.

Table 16. Gold association in Py concentrate.

\begin{tabular}{ccccc}
\hline Tane Boyu & $\mathbf{- 2 0 \mu m}$ & $\mathbf{- 4 5 + 2 0 \mu m}$ & $\mathbf{- 9 0 + 4 5 \mu m}$ & $\mathbf{- 1 8 0 + 9 0 \mu m}$ \\
\hline Nabit Altın & Nabit Altın & Nabit Altın & 0,00 & 0,00 \\
\hline Kalkopirit & 0,00 & 0,00 & 2,38 & 0,00 \\
Altere Kalkopirit & 0,00 & 0,00 & 0,00 & 7,29 \\
Bornit & 0,00 & 0,00 & 92,86 & 90,63 \\
Pirit & 16,67 & 14,29 & 0,00 & 0,00 \\
Altere Pirit & 0,00 & 4,76 & 0,00 & 2,08 \\
Galen & 0,00 & 0,00 & 2,38 & 0,00 \\
Kovelin & 0,00 & 0,00 & 2,38 & 0,00 \\
Matris & 83,33 & 80,95 & & \\
\hline
\end{tabular}
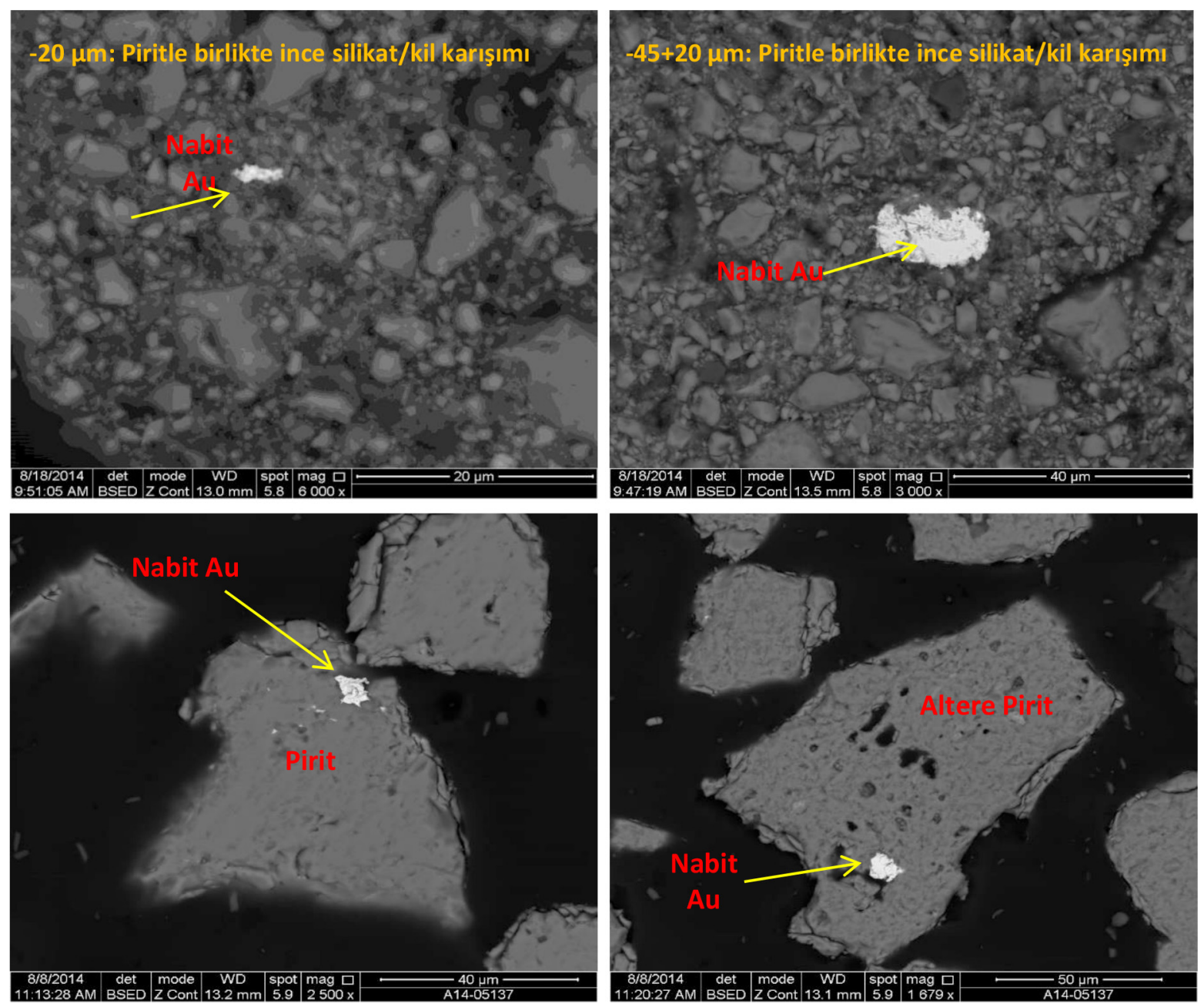

Şekil 7. Py konsantresindeki altın tanelerinin BSE görüntüleri.

Figure 7. BSE images of gold grains in Py concentrate. 


\section{Pirit konsantre}

Pirit konsantresinin QemSCAN ile analizi 4 tane boyu fraksiyonunda ağırlıkça yüzde bazında yapılmıș ve konsantrenin toplam $\mathrm{Cu}$ içeriğinin $\% 0,8$ olduğu, bunun da çoğunlukla $-90 \mu \mathrm{m}$ fraksiyonlarına dağıldığı belirlenmiștir. Fraksiyonel bazda modal mineraloji verileri Çizelge 15'te verilmektedir. Buna göre majör mineraller pirit ve altere pirit olup bazı silikatlar ve killere de rastlanmaktadır. Ana bakır minerali enargittir. Bu konsantrede altın taneleri beklenildiğinden daha az miktarda tespit edilmiș olup genellikle ince tane boyu fraksiyonlarındadır. Özellikle $-45+20 \mu \mathrm{m}$ ve $-20 \mu \mathrm{m}$ fraksiyonlarından tekrarlı parlak kesitler hazırlanarak analizler yinelenmiștir. Ancak sonucun değișmediği görülmüș, bu durum iki olasılıkla yorumlanmıștır:

- Görünür altının yanında, piritler içinde görünmez veya mikronaltı tane boyunda altın taneleri olabilir; bu da sadece EMPA (Electron Microprobe Analysis) veya Lazer ablasyon analizi ile belirlenebilir,

- Bu iki ince fraksiyonda, altın toz haline getirilmiș olabilir (altın sertliği: 2,5-3) ve toz halindeki altın tanelerinin mineral taneleri arasında gömülü ya da gizlenmiș halde bulunması olabilir. Altın arama için 1 mikron piksel boyutunun kullanıldığı ve tekrarlama analiz sırasında numunenin yaklaşık 1000 kat büyütmede ve hatta bazen 10000'de tarandığı düșünüldüğünde bu altın tanelerinin gerçekten çok ince boyda olması gerekmektedir.

$10 \mu \mathrm{m}$ 'den daha ince boyda görülen altın tanelerinin serbest yüzeylerinin oldukça sınırlı olduğu ve genellikle pirit ile ince silikat/kil/pirit karıșımının olduğu matrisle bağlı olduğu görülmüștür (Çizelge 16 ve Șekil 7).

\section{SONUÇLAR}

Detaylı kantitatif mineralojik analiz, altın içeren kompleks bir Cu-As sülfürlü cevherin tesis ölçeğinde flotasyon davranımının çok daha iyi anlașımasını sağlamıștır. Yapılan mineralojik ölçümler sayesinde tesisin genel performansı hakkında oldukça değerli bilgiler elde edilmiș, konsantre kirliliğini azaltacak ve verimi yükseltecek, tesis ișleyișine yönelik iyileștirmeler önerilebilmiștir. Varılan sonuçlar așağıdaki gibi özetlenebilir:
- Enargit ve tennantit minerallerinin serbestleșme derecesi $-45 \mu \mathrm{m}$ tane boyunda sadece $\% 60$ civarında olup bakır minerallerinin \%70'i bu boyun altında birikmektedir. Bu nedenle, serbestleșmeyi sağlayabilmek için daha ince tane boyuna öğütme yapmak gerekmektedir. Ancak, bu kararı vermeden önce kaba flotasyon artığındaki minerallerin serbestleșme ve bağlılık durumlarını kontrol etmek gerekir. Çünkü kaba flotasyon artığı hem nihai artığın ana bileșeni hem de bakırın \%7,6'lık kısmının kaybedildiği bir akıștır.

- Bakır konsantreyi kirleten ana unsurun serbest pirit mineral tanelerinin olduğu belirlenmiștir. Özellikle $45 \mu \mathrm{m}$ 'den daha iri boylarda serbest pirit tanelerinin varlığının flotasyon kimyasının uygun olmamasından kaynaklandığı düșünülmektedir. Bu anlamda toplayıcı tipi ve su kimyasının dikkate alındığı test çalışmalarının yapılması önerilmektedir.

- Flotasyon devresindeki en büyük bakır kaybının Cu süpürme artığı akıșından olduğu belirlenmiștir. Enargit ve tennantit mineralleri -20 $\mu \mathrm{m}$ fraksiyonundan \%60' serbest halde kaybedilmekte, bu da beslemedeki toplam bakır metalinin \%2,8'ine karșilık gelmektedir. Diğer bir deyișle saatte $101 \mathrm{~kg}$ bakır artığa gitmektedir. İnce tanelerin düșük verim probleminin kaynağı olarak așırı yüzey oksitlenmesi ve/ veya hücre hidrodinamiği öngörülmektedir. Bakır kaybına diğer bir sebep de kaba flotasyona devresine $\mathrm{Cu}$ süpürme konsantresi ve SFR2 artığından gelen yüksek devreden yüklerdir.

- Devredeki altının nabit ve Au-Sb alașım formunda olduğu da yine detaylı mineralojik analizlerle belirlenmiștir. $\mathrm{Cu}$ konsantresinden özellikle nabit altının çok ince tane boylarında yerçekimi ile kazanılabileceği öngörülürken, pirit konsantresinde altının serbest hale gelebilmesi için çok daha ince boyda besleme yapmanın gerekli olduğu belirlenmiștir.

\section{KAYNAKLAR}

Curreli, L., Ghiani, M., Surracco, M. And Orr, G., 2005. Beneficiation of a gold bearing enargite ore by flotation and As leaching with Na-hypochlorite. Minerals Engineering, 18, 849-854. 
Cabri, L.J., Beattie, M., Rudashevsky, N.S. and Rudashevsky, V.N., 2005. Process mineralogy of $\mathrm{Au}, \mathrm{Pd}$ and Pt ores from the Skaergaard intrusion, Greenland, using new technology. Minerals Engineering, 18, 887-897.

Lotter, N.O., Bradshaw, D.J. and Barnes, A.R., 2016. Classification of the Major Copper Sulphides into semiconductor types, and associated flotation characteristics. Minerals Engineering, 96-97, 177-184.

Fornasiero, D., Fullston, D., Li, C. and Ralston, J., 2001. Separation of enargite and tennantite from non-arsenic copper sulfide minerals by selective oxidation or dissolution. Int. J. Miner. Process., 61, 109-119.

Lund, C., Lamberg, P. and Lindberg, T., 2015. Development of a geometallurgical framework to quantify mineral textures for process prediction. Minerals Engineering, 82, 61-77.

Petruk, W., 2000. Applied Mineralogy in the Mining Industry. Elsevier Science, The Netherlands.
Plackowski, C., Nguyen, A. V. and Bruckard, W. J. 2012. A critical review of surface properties and selective flotation of enargite in sulphide systems. Minerals Engineering, 30, 1-11.

Sutherland, D., 1998a, Improving plant performance through process mineralogy. $\mathrm{Cu}$ ' 98 -Australian Copper Forum.

Sutherland, D., 1998b, Applications of quantitative process mineralogy through the mining cycle. AusIMM Annual Conference: The Mining Cycle, Mt Isa, Qld, pp. 333-337.

Sutherland, D., 2007. Estimation of mineral grain size using automated mineralogy. Minerals Engineering, 20, 452-460.

Tungpalan, K., Wightman, E. and Manlapig, E., 2015. Relating mineralogical and textural characteristics to flotation behaviour. Minerals Engineering, 82, 136-140. 
